\title{
Are credit ratings a good measure of capital adequacy?
}

\author{
D.E. Allen ${ }^{1}$, A.R. Kramadibrata ${ }^{1}$, R.J. Powell ${ }^{1}$ and A.K. Singh ${ }^{1}$ \\ ${ }^{1}$ Edith Cowan University, Western Australia \\ Email: a.kramadibrata@ecu.edu.au
}

\begin{abstract}
Focus on capital adequacy intensified since the onset of the Global Financial Crisis (GFC), with many US and other global banks experiencing capital shortages over this time. The Basel standardised approach uses credit ratings as a determinant for corporate capital adequacy requirements. A problem with credit ratings is that they were designed to be a measure of relative, as opposed to absolute credit risk, and do not ratchet up or down with changes in economic circumstances. This paper examines how credit risk as indicated by credit ratings (and their associated capital requirement) changed pre and post Global Financial Crisis for US firms, as compared to market measures of credit risk including credit default swaps and fluctuating market asset values. The increases in credit risk shown by the credit ratings and the market indicators are compared to actual bad debt levels of banks.
\end{abstract}

We use an extensive database comprising investment as well as speculative grade US firms. In order to measure the fluctuations in market asset values of these firms, we apply quantile regression and Monte Carlo simulation to the Merton structural credit model. This model uses asset fluctuations in conjunction with balance sheet structure to estimate Distance to Default (DD) and Probability of Default (PD). The use of quantile regression allows modelling of the extreme quantiles of a distribution which facilitates measurement of PDs at the most extreme points of downturn, when companies are most likely to fail. The study shows how the quantile analysis can be used to estimate capital buffers required by banks to deal with increases in credit risk.

We find that changes in capital requirements over the GFC as measured by credit ratings are very small in relation to the increase in credit risk identified by market based measures and our quantile regression analysis. These findings can be important to banks and regulators in determining capital adequacy in volatile economic circumstances.

Keywords: credit risk, quantile regression, probability of default, Monte Carlo simulation, capital adequacy. 


\section{INTRODUCTION}

The global financial crisis (GFC) highlighted the devastating effect that high credit risk can have on financial markets. US banks experienced capital shortages, losses (for example, nearly $\$ 50$ billion by the major banks in 2008) and rating downgrades. Several banks failed (25 Banks in 2008 and 140 in 2009), the most notable being the demise of Lehman Brothers. Table 1 shows that, during the GFC US bank impaired assets increased by approximately threefold. The evidence shows that US banks and firms were not adequately prepared for the extreme economic downturn, raising questions regarding the ability of banks and firms to accurately measure capital reserves required to absorb risk in extreme situations. Against this background, this paper addresses the viability of credit ratings as a measure of credit risk using the Basel standardised model. We will compare capital adequacy requirements indicated by the Basel model with a market based model (quantile regression applied to the Merton structural model).

Table 1 Impaired Assets - US Banks

\begin{tabular}{cc} 
& $\begin{array}{c}\text { Impaired } \\
\text { Assets }\end{array}$ \\
\hline Mar-2000 & $1.85 \%$ \\
Mar-2001 & $2.13 \%$ \\
Mar-2002 & $1.94 \%$ \\
Mar-2003 & $1.64 \%$ \\
Mar-2004 & $1.41 \%$ \\
Mar-2005 & $1.36 \%$ \\
Mar-2006 & $1.46 \%$ \\
Mar-2007 & $2.35 \%$ \\
Mar-2008 & $4.79 \%$ \\
Mar-2009 & $8.80 \%$ \\
\hline
\end{tabular}

US figures include commercial banks as classified by the Federal Reserve Bank (FRB), and all figures are obtained from FRB (2000) statistical reports. Impaired asset figures comprise loans classified as delinquent, which are loans past thirty days or more and still accruing interest as well as those in nonaccrual status, measured as a percentage of end-of periods.

The Basel standardised approach uses credit ratings as a determinant for capital adequacy. Basel requires 8 per cent of risk-weighted assets to be held as capital for credit risk, with risk weightings shown in Table 2 .

Table 2 Basel Standard Approach

\begin{tabular}{|c|c|c|c|c|c|}
\hline Rating & $\begin{array}{c}\text { AAA to } \\
\text { AA- }\end{array}$ & $\begin{array}{c}\text { A+ to } \\
\text { A- }\end{array}$ & $\begin{array}{c}\text { BB+ to } \\
\text { BB- }\end{array}$ & $\begin{array}{c}\text { Below } \\
\text { BB- }\end{array}$ & Unrated \\
\hline $\begin{array}{c}\text { Risk } \\
\text { weighting }\end{array}$ & $20 \%$ & $50 \%$ & $100 \%$ & $150 \%$ & $100 \%$ \\
\hline
\end{tabular}

The Basel model has universal application, being used by more than 100 countries, including G20 countries.

A problem with credit ratings is that, according to external raters, (Standard \& Poors, 2009), they are designed to only be a measure of relative, as opposed to absolute credit risk, and do not fluctuate as economic circumstances change. If the underlying rating of the borrower doesn't change then neither does their capital requirement.

Using a portfolio of S\&P 500 and Moody's Speculative grade entities (Moody's Investor services, 2010), we explore the question as to whether changes in credit ratings pre-GFC to GFC accurately reflect actual changes in credit risk over this period. We find that capital adequacy requirements based on external ratings change only marginally over this period, as compared to market risk indicators such as credit default swaps. 
The study then goes to show how quantile regression and Monte Carlo simulation can be applied to the Merton structural credit model, to measure changes in fluctuations in credit risk between the pre-GFC and GFC periods. By using this unique approach we are able to measure default probabilities at the extreme quantiles of the distribution. We further go on to calculate the estimated capital buffer required to deal with this level of risk, which we find significantly exceeds that indicated by the Basel standardised approach. The Basel capital percentages, including buffers required by Basel III, only represents minimum requirements, and do not obviate the need for banks to understand and manage their own capital adequacy, which may be above regulatory minimums. The approaches shown in this paper can assist banks and regulators better understand their capital reserves and manage this process.

\section{DATA AND METHODOLOGY}

\subsection{Data}

Data is divided into two periods: Pre-GFC and GFC. Our Pre-GFC period includes the 7 years from January 2000 to December 2006. This 7 year period aligns with Basel Accord advanced model credit risk requirements. Our GFC period includes January 2007 to June 2009.

For our Merton / KMV based models which require equity prices, we obtain daily prices from Datastream (approximately 250 observations x 10 years $=2500$ observations per company). Required balance sheet data for the structural model, which includes asset and debt values, is also obtained from Datastream. To ensure a mix of investment and speculative entities, we obtain data from two sources: firstly, entities listed on the New York Stock Exchange (NYSE) Standard \& Poor's 500 index (S\&P 500); secondly, entities included in Moody's Speculative Grade Liquidity Ratings list (Moody's Investor Services, 2010). In both cases we only include rated entities, for which equity prices and Worldscope balance sheet data are available in Datastream. Entities with less than 12 months data in either of the 2 periods are excluded. This results in 366 entities consisting of 202 S\&P 500 companies and 164 speculative companies.

\subsection{Distance to Default (DD) and Probability of Default}

The Merton / KMV approach (which we use in this study, but modify to incorporate quantiles) provides an estimate of distance to default (DD) and probability of default (PD). The model holds that there are 3 key determinants of default: the asset values of a firm, the risk of fluctuations in those asset values, and leverage (the extent to which the assets are funded by borrowings as opposed to equity). The firm defaults when debt exceeds assets, and DD measures how far away the firm is from this default event. KMV (Crosbie \& Bohn, 2003), in modelling defaults using their extensive worldwide database, find that firms do not generally default when asset values reach liability book values, and many continue to service their debts at this point as the long-term nature of some liabilities provides some breathing space. KMV finds the default point to lie somewhere between total liabilities and current liabilities and therefore use current liabilities plus half of long term debt as the default point.

$$
\begin{array}{r}
D D=\frac{\ln (V / F)+\left(\mu-0.5 \sigma_{V}^{2}\right) T}{\sigma_{V} \sqrt{T}} \\
P D=N(-D D)
\end{array}
$$

Where:
$\mathrm{V}=$ market value of firm's assets
$\mathrm{F}=$ face value of firm's debt (in line with KMV, this is defined as current liabilities plus one half of long term debt)
$\mu=$ an estimate of the annual return (drift) of the firm's assets (we measure $\mu$ as the mean of the change in $\ln \mathrm{V}$ of the period being modelled as per Vassalou \& Xing (2004)
$\mathrm{N}=$ cumulative standard normal distribution function. 
To estimate asset volatilities and arrive at DD, we follow an intensive estimation, iteration and convergence procedure, as outlined by studies such as Bharath \& Shumway (2008), Vassalou \& Xing (2004), and Allen and Powell (2009).

\subsection{Quantile Regression}

Quantile regression per Koenker \& Basset (1978) and Koenker and Hallock (2001) is a technique for dividing a dataset into parts. Minimising the sum of symmetrically weighted absolute residuals yields the median where 50 percent of observations fall either side. Similarly, other quantile functions are yielded by minimising the sum of asymmetrically weighted residuals, where the weights are functions of the quantile in question per equation 3 . This makes quantile regression robust to the presence of outliers.

$$
\min _{\varepsilon \in R} \sum p_{r}\left(y_{1}-\varepsilon\right)
$$

where $p_{\tau}($.$) is the absolute value function, providing the \tau$ th sample quantile with its solution.

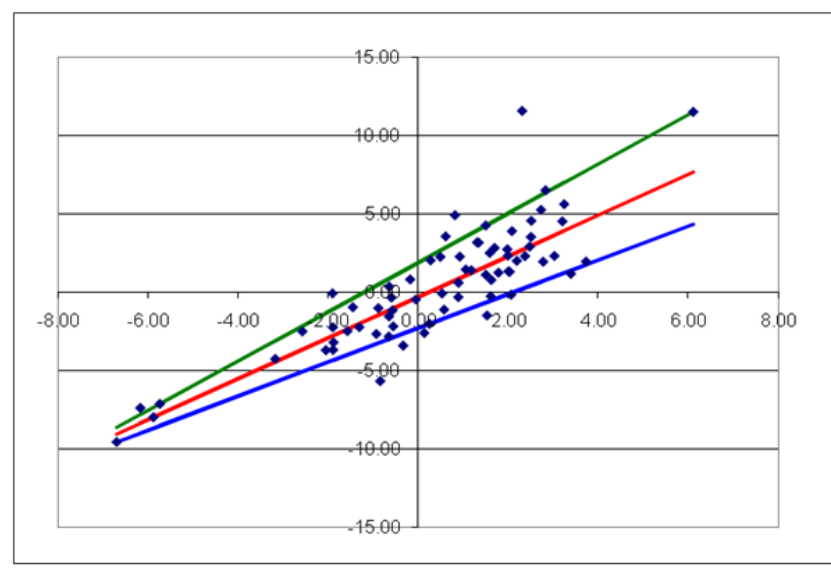

Figure 1 (Steiner, 2006) illustrates the quantile regression technique. The $\mathrm{x}$ and $\mathrm{y}$ axes represent any two variables being compared (such as age and height; or market returns and individual asset returns). The 50 percent quantile (middle line) is the median, where 50 percent of observations fall below the line and 50 percent above. Similarly, the 90 percent quantile (top line) is where 10 percent of observations lie above the line, and 10 percent quantile (bottom line) has 90 percent of observations above the line. The intercept and slope are obtained by minimising the sum of the asymmetrically weighted residuals for each line.

Figure 1 Illustrative Quantile Regression example

Quantile regression allows direct modelling of the tails of a distribution rather than 'average' based techniques such as ordinary least squares or credit models which focus on 'average' losses over a period of time. The technique has enjoyed wide application such as investigations into wage structure (Buschinsky, 1994; Machado \& Mata, 2005), production efficiency (Dimelis \& Lowi, 2002), and educational attainment (Eide \& Showalter, 1998). Financial applications include Engle \& Manganelli (2004) and Taylor (2008) to the problem of VaR and Barnes and Hughes (2002) who use quantile regression analysis to study CAPM in their work on stock market returns.

In a stock market context Beta measures the systematic risk of an individual security with CAPM predicting what a particular asset or portfolio's expected return should be relative to its risk and the market return. The lower and upper extremes of the distribution are often not well fitted by OLS. Allen, Gerrans, Singh, \& Powell (2009), using quantile regression, show large and sometimes significant differences between returns and beta, both across quantiles and through time. These extremes of a distribution are especially important to credit risk measurement as it at these times when failure is most likely. We therefore expand these quantile techniques to credit risk by measuring Betas for fluctuating assets across time and across quantiles, and the corresponding impact of these quantile measurements on DD. This is shown in Figure 2 in the results section, where our $y$ axis depicts the asset returns for the quantile being measured (we measure the 50 percent quantile which corresponds roughly to the standard Merton model, and the 95 percent quantile), and the $x$ axis represents all the asset returns (all quantiles) in the dataset.

Using actual returns provides us with only a limited number of extreme returns with which to model the quantiles. To increase the richness of the data we use Monte Carlo simulation to generate 20,000 simulated asset returns for every company in our dataset (see Allen, Kramadibrata, Powell \& Singh, 2010, 2011, 2011a and Allen, Boffey \& Powell, 2011). This is done by generating 20,000 random numbers based on the standard deviation and mean of historical asset returns. 


\section{RESULTS}

Table 3 shows ratings for all entities in our dataset. We use the S\&P rating system to which Moody's rating s have been mapped, and the risk weightings that apply according to the Basel II standardised model. The table shows a slide from AAA rated entities to A and BB. This change in ratings should be met with an increased capital requirement which we don't see happening. A bank holding this portfolio of assets would observe its capital requirement increase only marginally, from $3.63 \%$ to $3.98 \%$. This indicates that according to the Basel model, there has been minor change in credit risk since the start of GFC.

Table 3 Risk Weightings and Capital Requirements

\begin{tabular}{|c|c|c|c|}
\hline Rating & $\begin{array}{c}\text { Risk } \\
\text { Weighting }\end{array}$ & $\begin{array}{c}\text { Pre-GFC \% of } \\
\text { portfolio in this } \\
\text { category }\end{array}$ & $\begin{array}{c}\text { GFC \% of } \\
\text { portfolio in } \\
\text { this category }\end{array}$ \\
\hline AAA to AA- & $20 \%$ & $34.59 \%$ & $14.28 \%$ \\
A+ to A- & $50 \%$ & $44.44 \%$ & $61.99 \%$ \\
BB+ to BB- & $100 \%$ & $17.63 \%$ & $21.46 \%$ \\
Below BB- & $150 \%$ & $3.34 \%$ & $2.26 \%$ \\
$\begin{array}{c}\text { Capital Required as \% } \\
\text { of Total Assets }\end{array}$ & & $4.14 \%$ & $4.69 \%$ \\
\hline
\end{tabular}

Column 1 shows the external credit rating. Risk weightings in column 2 reflect Basel requirements for corporate. Capital requirement is measured as 8 per cent of risk-weighted assets in line with Basel. This is shown as a percentage of total assets in the final row of the table.

We calculate DD for each entity using the methodology outlined in Section 2.2. Quantiles for each period (GFC, pre-GFC) are calculated as per Section 2.3, with two fundamental differences. Firstly, quantile Beta analysis is normally applied to share prices, whereas we are using daily market asset values (calculated in Section 2.2). Secondly, Betas for shares are normally measured as returns of individual share against market. We instead are comparing risk measurements between two periods (GFC, pre-GFC) and between different quantiles in these periods.

Figure 2 shows the asset value fluctuations $(\sigma)$, the associated Beta $(\beta)$ and DD. The graph shows large differences in DD, for example the pre-GFC and GFC 50\% quantile shows a hefty change from 8.09 to 3.8 . The difference between asset value fluctuations at the $95 \%$ quantile compared to the $50 \%$ quantile is significant at the 99 percent confidence level using $\mathrm{F}$ tests for changes in volatility. This has significant implications for Banks. Provisions and capital calculated on 'average' or below the threshold measurements for a portfolio of corporate assets will clearly not be adequate during periods of extreme downturn.

The graph also shows the 'median' DD (based on how the standard Merton structural model calculates DD) over the 10 year study period was 5.98 with an asset value standard deviation $(\sigma)$ of 0.00789 . As asset value $(\sigma)$ is the denominator of the DD equation (equation 1), as $\sigma$ increases (reduces) from one level to another (i.e. from $\sigma_{1}$ to $\sigma_{2}$ ) DD reduces (increases) by the same proportion. Thus the numerator of the equation (a measure of capital - the distance between assets and liabilities) needs to increase to restore DD for these Corporates back to the same level, i.e. capital will need to increase by the same proportion as the change in DD (which from the ten year median to the worst quantile in the graph was approximately $3 \mathrm{x}$ ).

When we compare the Basel model with the quantile regression model in respect to indicated changes in capital requirements, the Basel approach comes up very short. The Basel model showed very little change in overall credit risk between the two periods (Pre-GFC, GFC). This marginal change does not reflect the large change in market asset values (and corresponding change in capital required of 3 times during extreme downturn) shown by our application of quantile regression to the Merton structural model. 
Figure 2 Quantile Results

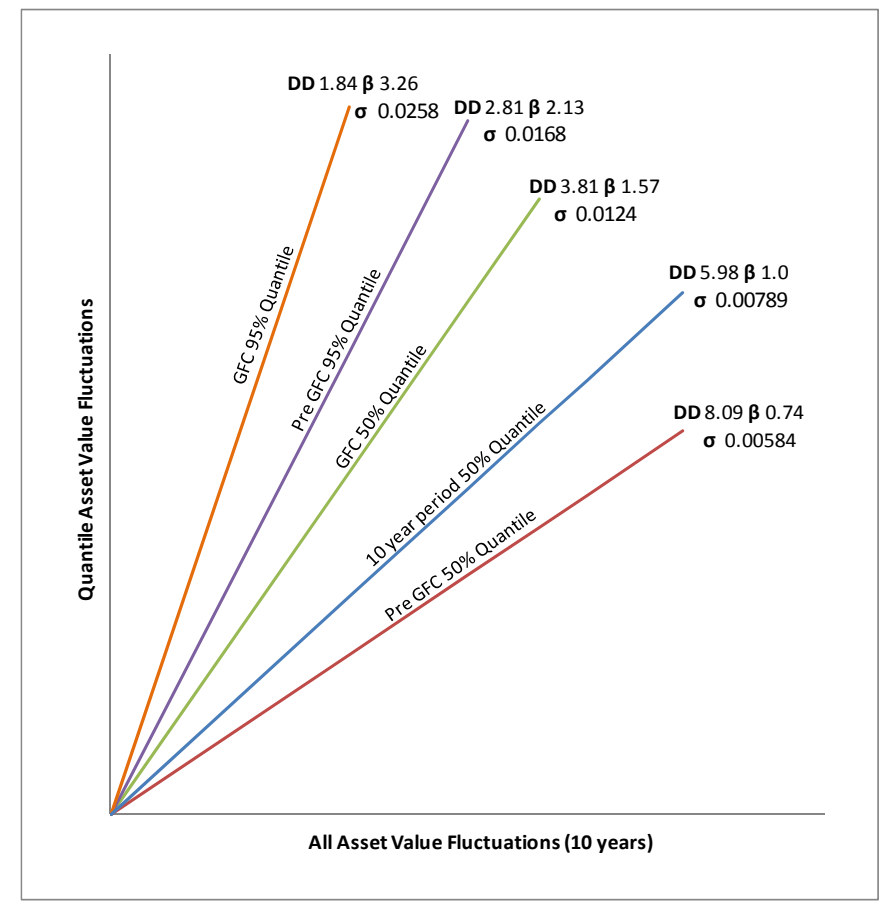

The graph shows the results of the Quantile Regression Model for the 50 percent and 95 percent quantiles for pre-GFC and GFC periods. The pre-GFC period is the 7 years between $2000-2006$ whereas the GFC period is the 3 years between $2007-2009$. The $y$ axis is calculated on asset fluctuations $(\boldsymbol{\sigma})$, using the Merton model, for the quantile in question. The $x$ axis is the median $\boldsymbol{\sigma}$ for the entire 10 year period. Thus the Beta $(\boldsymbol{\beta})$ for the 50 percent quantile is one. Where $\boldsymbol{\sigma}$ for a particular quantile is less (greater) than the median for the 10 year period, $\beta<(>) 1$, and DD increases (reduces) accordingly.

\section{CONCLUSION}

This paper has compared the ratings based Basel standardised approach to measuring credit risk to a marketbased model that reflects the fluctuations in market asset values. The Basel model does not recognise these fluctuations in credit risk, as it only measures credit risk at a certain point in time, with ratings reviewed only periodically (often annually). This is why credit ratings may not be a good indicator of capital requirements in turbulent times.

Our quantile regression application to the Merton structural model, on the other hand, shows significant increase in credit risk that translates to a corresponding increase in the capital buffer required to deal with that risk. The threefold increase of DD (10 year median to 95\% GFC quantile) mirrors the increase in impaired assets from $2006-2009$ as shown in Table 1. Thus the quantile model is more accurately reflecting changes in credit risk than the ratings based approach.

These findings can be important to banks and regulators in determining capital adequacy in volatile economic circumstances.

\section{ACKNOWLEDGEMENTS}

Allen and Powell would like to thank the Australian Research Council for funding support.

\section{REFERENCES}

Allen, D.E., Gerrans, P., Singh, A. K., \& Powell, R. (2009). Quantile Regression: Its Application in Investment Analysis. Jassa(4), 7 - 12.

Allen, D. E., \& Powell, R. (2009). Structural Credit Modelling and its Relationship to Market Value at Risk: An Australian Sectoral Perspective. In G. N. Gregoriou (Ed.), The VaR Implementation Handbook (pp. 403-414). New York: McGraw Hill. 
Allen, D. E., Kramadibrata, A.R., Powell, R.J., \& Singh, A.K. (2010). Using Quantile Regression to Estimate Capital Buffer Requirements for Japanese Banks. Paper presented at the Globalization, Monetary Integration and Exchange Rate Regimes in East Asia Conference. Perth.

Allen, D. E., Kramadibrata, A.R., Powell, R.J., \& Singh, A.K. (2011). Comparing Australian and US corporate default risk using quantile regression. Econometrics Society Australasian Meeting. Adelaide.

Allen, D. E., Kramadibrata, A.R., Powell, R.J., \& Singh, A.K. (2011a). Xtreme credit risk models: Implications for bank capital buffers. Paper presented at the Systematic Risk, Basel III, Financial Stability and Regulation Conference. Sydney.

Allen, D. E., Boffey, R. R., \& Powell, R, J. (2011). A Quantile Monte Carlo Approach to Measuring Extreme Credit Risk. Working Paper, Edith Cowan University.

Barnes, M. L., \& Hughes, A. W. (2002). A Quantile Regression Analysis of the Cross Section of Stock Market Returns. Working Paper 02-2, Federal Reserve Bank of Boston.

Basel Committee on Banking Supervision. (2008). Consultative proposals to strengthen the Resilience of the Banking Sector Announced by the Basel Committee, 17 December, 2008.

Bharath, S. T., \& Shumway, T. (2008). Forecasting Default with the Merton Distance-to-Default Model. The Review of Financial Studies, 21(3), 1339-1369.

Buschinsky, M. (1994). Changes in the US Wage Structure 1963 - 1987: Application of Quantile Regression. Econometrica, 162(2), 405 - 458.

Crosbie, P., \& Bohn, J. (2003). Modelling Default Risk: Moody's KMV Company.

Dimelis, S., \& Lowi, H. (2002). Oxford Economic Papers. Oxford University Press, 20(4), 445 - 465.

Eide, E., \& Showalter, M. H. (1998). The effect of school quality on student performance: a quantile regression approach. Economics Letters, Elsevier, 58(3), 345 - 350.

Engle, R., \& Manganelli, S. (2004). CAViaR: Conditional Autoregressive Value at Risk by Regression Quantiles Journal of Business \& Economic Statistics, 22(4), 367-381.

Federal Reserve Bank. (2010). Federal Reserve Statistical Release: Charge-off and Delinquency Rates. Retrieved 13 March 2011. Available at www.federal reserve.gov

Koenker, R., \& Bassett, G., Jr. (1978). Regression Quantiles. Econometrica, 46(1), 33-50.

Koenker, R., \& Hallock, K, (2001). Quantile Regression. Journal of Economic Perspectives. 15(4), 143 156.

Machado, J., \& Mata, J. (2005). Counterfactual Decomposition of Changes in Wage Distributions Using Quantile Regressions. Journal of Applied Econometrics, 20(4), 445 - 465.

Moody's Investor Services. (2010). Moody's Speculative Grade Liquidity Ratings. Retrieved 31 September 2010. Available at www.moody's.com

Standard \& Poor's. (2009). Default, Transition and Recovery: Annual Global Corporate Default Study and Rating Transition. Retrieved 12 August 2009. Available at www.standardandpoors.com

Standard \& Poor's. (2009). Guide To Credit Ratings Essentials. Retrieved 9 June 2011. Available at www.standardand poors.com

Steiner, A. (2006). Investment Performance Analysis and Risk Management. Retrieved 20 July 2011. Available at http://www.andreassteiner.net/performanceanalysis.

Taylor, J. W. (2008). Using Exponentially Weighted Quantile Rergression to Estimate Value at Risk and the Expected Shortfall. Journal of Financial Econometrics, 6(3), 282 - 406.

Vassalou, M., \& Xing, Y. (2004). Default Risk in Equity Returns. Journal of Finance, 59, 831-868. 